\title{
CAN THERE BE A COMPETITOR TO TRADITIONAL ARABLE CROPS IN ROMANIA?
}

\author{
Margit Csipkés \\ Institute of Sectoral Economics and Methodology, Faculty of Economics and Business, \\ University of Debrecen, Debrecen, Hungary \\ csipkes.margit@econ.unideb.hu
}

\begin{abstract}
Regarding land use, in the member states of the European Union it can be established that maize is the most productive traditional arable crop. The annual productive area of maize in 2015 was approximately 9.33 million hectares in the EU 28, which was 3\% less than that of 2014. There was also a reduction in average production, which, according to member states' figures decreased to 6.15 tonnes/ hectare. This reduction is due to the worsening natural conditions. Consequently, the year's production was about 57 million tonnes at the end of 2015. This represented a reduction of 25\% compared to 2014 . The second largest production crop in the EU 28 is wheat, although here, too, a reduction can be observed when the data for the last 5 years is examined. This reduction in crop production prompts arable farmers to engage in the production of other crops in those areas where there is a continual reduction in crop production. In my study I will introduce the profitability and risks associated with those plants suited for energy extraction, which can be competitive with the traditional arable plant cultivation.
\end{abstract}

Keywords: traditional arable crop, risk, energy, energy plants.

JEL classification: O13, P18, Q42.

\section{Romanian agriculture in 2015}

On the basis of data from the National Institute of Statistics, the extent of agricultural territory decreased, compared to the previous year. On the basis of data for the last 10 years (NISA, 2012, OECD-FAO, 2010), this reduction is equivalent to about 1 million hectares. The official data records that agricultural areas (arable, pasture, feed crops) hardly reached 13 million hectares at the end of 2014. This means that Romania accounts for about 7 per cent of the Union's agricultural territory. In first place is France with 28 per cent ( 27.8 million hectares), followed by Spain with 13.60 per cent (23.75 million hectares), Great Britain with 9.7 per cent (16.88 million hectares), Germany with 9.6 per cent (16.7 million hectares) and Poland with 8.3 per cent (14.4 million hectares) (NISA, 2016).

In Romania the average farm size is 3.6 hectares, which is four times smaller than the Union average ( 14.2 hectares). The greatest farm size in the EU 28 member states in 2015 is found in the Czech Republic, with 152.4 hectares, followed by Great Britain (90.4 hectares), Italy (79 hectares), Germany (55.8 hectares) and France (54 hectares). Naturally, the average does not give sufficient information about the size of the owning entities, since owners without a legal entity (e.g. farms maintained by sole proprietors) had farms which averaged 2 hectares, whereas farms with legal entity owners were about 200 hectares in size, according to figures for 2015.

Despite the small size of farms compared to the Union average, about one third of all farms operating in the EU are found in Romania (32\%). The division of agricultural land is 63 per cent arable, 33.7 per cent pasture and feed crops, 2.3 per cent fruit and vines, and 1.2 per cent family gardens. 
In plant production - according to the size of the area devoted to different crops - Romania is in the leading position for maize and sunflowers, since almost a quarter of the area devoted to these crops can be found in Romania. In the case of wheat, Romania is in fifth place, behind France, Germany, Poland and Spain.

\section{The economic importance of energy crops}

From the brief introduction to Romanian agriculture it can be seen that at the present time about 13 million hectares of land are given over to arable crops, while at the same time there are several hundred thousand hectares where even with the current support system it is difficult to ensure a profitable production from traditional arable crops. However, on these low productivity soils woody and herbaceous energy plants can be grown productively. In fields with high water tables these are primarily types of willow tree, while in areas with less water, they include the poplar, the acacia, Miscanthus (Chinese reed); and in clearly dry areas, energy grass. A more recent possibility is the Italian reed (Arundo D.) and giant Silphium perfoliatum.

In addition to herbaceous energy plants, there is a possibility to grow energy seedlings, a method which does not require any change in the way the arable land is farmed, which also means that the subsidy for arable crops will be received by the farmer. The crop production cycle of the energy plants is, however, longer than that of arable crops. Through long term supplier contracts energy crops can represent a reliable and safe source of income, which, given the continually changing market conditions, the extremes of climate and the expected reduction in the European Union agricultural support, is something which is increasingly important for farmers.

\section{Brief introduction to energy plants}

One of the advantages of energy plants is that there is no (or hardly any) need for basic technical-technological changes in the cultivation method, and the biomass produce can be harvested annually - in some cases more frequently -, and because of the plants' life cycle the number of harvests is high and they cannot be delayed.

Herbaceous plants (the monocot species among them) make up the significant share of agricultural crops (the main ones include cereals, such as wheat, barley, oats and rye; and to a lesser extent sugar beet and cane sugar etc.). The seeds, roots and sometimes stalks of these plants are high sources of starch, and through various processes can thus be sources of bio-fuels and energy.

The other herbaceous group are the perennial herbaceous plants, which are rapidly growing grass and reed species (e.g. the Italian reed - Arundo Donax), which can serve as both a source of high energy feed and basic energy material.

Outside these two groups there is, for example, the energy reed (Miscanthus) group, which requires less water and so can be a good crop for agricultural areas with lower water supplies.

\subsection{The biomass potential of energy plants}

Agriculture is one of the sectors with the greatest biomass potential, since energy plants and the bi-products of agricultural production - can be introduced into energy production. The biomass potential of individual energy plants can be seen in Table 1. As can be seen, in Romania, too, maize is the leading traditional arable crop, and so the energy potential of maize bi-products must also be investigated, since bi-products and waste material also have a significant energy potential, which can contribute to energy management (Table 2).

The energy sources listed in Tables 1 and 2 can be processed by the help of various basic technologies: direct burning (electricity/heat production), anaerobic decomposition, 
fermentation (alcohol produced from sugar), oil extraction, pyrolysis and gasification. The basic technologies are often supplemented with secondary processes (stabilisation, drying, improving, refining) in order to produce the end product. Of course, the process employed always depends on the basic material involved.

In the following section I will introduce the herbaceous energy plants under examination, since we know less about them compared to the traditional arable crops.

Table 1: Productivity indices of biomass energy crops

\begin{tabular}{|c|c|c|c|c|}
\hline $\begin{array}{c}\text { Energy } \\
\text { crops }\end{array}$ & $\begin{array}{c}\text { Biomass } \\
\text { type }\end{array}$ & $\begin{array}{c}\text { Biomass } \\
\text { production } \\
\mathbf{t}_{\text {dm }} / \mathbf{h a}^{*}\end{array}$ & $\begin{array}{c}\text { Moisture content } \\
\text { at harvest \% }\end{array}$ & $\begin{array}{c}\text { Wet calorific } \\
\text { value MJ/kg }\end{array}$ \\
\hline Crop & seed-crop & $4.1-9.2$ & $12-14$ & 16.5 \\
\hline \multirow{2}{*}{ Maize } & corn-stalk & $8.34-10.6$ & $59-64$ & 17 \\
\cline { 2 - 5 } & corn grain & $7.09-8.34$ & $19-24$ & $16-17$ \\
\hline $\begin{array}{c}\text { Giant reed } \\
\text { (Arundo } \\
\text { Donax) }\end{array}$ & stem, leaf & $20-30$ & 40 & $17.3-17.6$ \\
\hline Miscanthus & stem, leaf & $11-34$ & $50-60$ & 37.7 \\
\hline Sunflower & seed-crop & $3.0-3.9$ & 9 & 37.6 \\
\hline Rape & seed-crop & $1.4-2.0$ & 9 & $17.7-17.8$ \\
\hline Locust-tree & Wood & $10.0-13.0$ & $50-60$ & $17.7-18$ \\
\hline Poplar & Wood & $9.0-12.5$ & $50-60$ & $17.8-18.4$ \\
\hline Willow & Wood & $10.00-15.0$ & $50-60$ & \\
\hline
\end{tabular}

${ }^{*}$ Annual biomass productivity denotes the amount of dry matter

Source: ENER, 2012

\subsection{Description of herbaceous energy plants involved in the comparison and their technological requirements}

In my research, in addition to the traditional arable crops, I also deal with Italian reed, Chinese reed and Silphium.

The first herbaceous plant is the Italian reed (Arundo donax), or Arundo for short. This plant is a familiar decorative plant found in domestic gardens. It does not require a lot of care, and can grow to between 4 and 6 metres. In terms of costs, the plantation costs of reeds in the perennial grass group of plants are quite high, since propagating the plants with the rhyzome, the stalk, or the shoots, is very expensive. The advantage, however, is that in the years following plantation the plants can be maintained at low cost. They can be planted on a commercial scale in areas which are currently growing wood crops, for example for chipboard, fibreboard, etc. (Horváth et al., 2009).

The life cycle of the plant, on the basis of past experience, can reach 20 years, and in that period the costs of planting, and preparing the soil represent the greatest proportion of the costs and labour. 
Table 2: By-product values of agricultural products

\begin{tabular}{|c|c|c|c|c|c|}
\hline $\begin{array}{c}\text { Agricultural } \\
\text { crops }\end{array}$ & $\begin{array}{c}\text { Biomass } \\
\text { type }\end{array}$ & $\begin{array}{c}\text { Remaining } \\
\text { money } \\
\text { (rest/primary } \\
\text { product) }\end{array}$ & $\begin{array}{c}\text { Biomass } \\
\text { production } \\
\mathbf{t}_{\mathrm{dm}} / \mathbf{h a} \text { * }\end{array}$ & $\begin{array}{c}\text { Former } \\
\text { harvest } \\
\text { moisture } \\
\%\end{array}$ & $\begin{array}{c}\text { Net } \\
\text { calorific } \\
\text { value } \\
\mathbf{M J} / \mathbf{k g}\end{array}$ \\
\hline Wheat & Straw & $1.0-1.66$ & $2.5-5.0$ & $10-13$ & $17.5-19.5$ \\
\hline Raize & $\begin{array}{c}\text { stem, the axis } \\
\text { of the } \\
\text { thickened } \\
\text { parts of } \\
\text { plants }\end{array}$ & $1.09-1.5$ & & & \\
\hline & $\begin{array}{c}\text { stem, the axis } \\
\text { of the } \\
\text { thickened } \\
\text { parts of } \\
\text { plants }\end{array}$ & 1.6 & $4.0-6.0$ & $40-60$ & $13.8-17.6$ \\
\hline Sunflower & stem and leaf & $0.7-1.3$ & $1.7-4$ & $14-20$ & $15.2-17.9$ \\
\hline
\end{tabular}

Source: ENER, 2012

The second herbaceous plant is the Miscanthus (Chinese reed), a perennial plant with root stalks, which can winter in continental climates and is a native of East Asia. On the basis of Hungarian planting experience, even without irrigation it can easily achieve a yield per hectare of between 20 and 25 tonnes. The life expectancy of the plant varies from 20 to 25 years. The Miscanthus can be used in the following ways: for energy purposes (small bales, large bales, pellets) as well as other purposes (straw litter, paper, reed matting). In Hungary there are currently 500 hectares of energy reed under cultivation, but 400,000 hectares would be the minimum required because of the integration network and the logistical organisation. This would provide eight per cent of Hungary's entire energy needs.

The third herbaceous plant is the Silphium, whose flowering period is approximately 60 to 70 days, because in the period in which the first crop is ripe (the mature seeds can easily spin; from the beginning of the vegetation period until the appearance of the first mature seeds in their beds requires 140-160 days), the central flowers are only blooming, and the upper levels are only at the initial stages of flowering.

\subsection{Analysis of the comparability of the plants involved in the investigation}

During the course of the research I investigated winter wheat, maize, sunflowers, and, from among the herbaceous plants, the Italian reed, the Chinese reed and Silphium, in terms of their cost-income relationships.

The database is made up of the natural technology for each plant, the material, operational and other costs related to the technology, and the yields and the prices of the yields. When preparing the technologies I calculated for an average asset stock and an average intensity. The aim was to examine the relative competitiveness of the different crop cultures on a production site with average or slightly below average characteristics. When establishing the average crop I tried to calculate real values for work carried out with appropriate care in a Romanian context. The basic calculations for an average crop were: 15-30 tonnes per hectare for Arundo, 10-25 t/ha for Miscanthus, and 20 t/h for Silphium (Robertson, 1984, Harmat e al., 2011). For the traditional arable crop plants I calculated the yields obtained on well-known areas with weaker characteristics. 
During the data collection I made contact with 12 producers, who provided me with their business databases (plans, log book tables), and also with more information in deep interviews.

First I did a preliminary survey and than I selected the producers. I checked the average capability in the present producer structure (growing area size, livestock, machinery, number of employees within the enterprise, geographical location) and the selection of the 12 producers were based on these informations. When I did the selection, it was important that the sampling has to be representative. During the data collection all the producers declared to not to indicate their names in my article.

I carried out the technological modelling on a 12 year period. Naturally, the annual technical interventions are repeated in the case of the classic arable plants, while for the energy plants they occur after every third year. An exception to this is Sulphium, where a loosening of the soil should be carried out every fourth year. The pressure of technology and changes in prices were calculated into the income on the basis of an annual growth of $2 \%$. We calculated the expenditure on the basis of an annual average increase of $5 \%$, because the rise in agricultural prices is not expected to reduce in the medium term. We publish the results on the basis of a twelve year total and for individual years, as well.

Calculated on the basis of the cost of cost categories may be treated by that material cost, material and services cost, the person the nature of cost, depreciation, and other expenses. The appropriate cost structure in order to develop the costs of discrimination I planted seeds direct costs (direct) and general costs (indirect).

Whereas the main purpose of entrepreneurial activity and that the available resources are efficiently used, so I reviewed the necessary resources for all tested plant.

Calculation of cost per action econometrics sectoral structure is applied most commonly used harvest, plant care, pest control, irrigation, transportation, drying, tillage, nutrient supply, sowing.

This was necessary because the practitioners primarily working operations are thinking. This is directly derived from technological operations cost structure.

Profitability calculations of the following categories were created.

$\checkmark$ Income: It was just calculating the actual sales, that is the monetary value of the realized earnings figured out. The formula used for calculation: Income $=$ sales returns - unite price

$\checkmark$ Direct cost: here are the costs I have mentioned that the test plant production sector produced final product and by-product production incurred.

$\checkmark$ All costs: the test plant production sector of final product and by-product used in order to charges, value for money. The formula used for calculation: All $\cos t=$ input $*$ unite price + other income with no exp ense content

$\checkmark$ Net income: this income category Income relationship characterized by each company. Published directly on the device use. The formula used for calculation: Revenue above = production value $-\cos t$ of production

$\checkmark$ Coverage amount: the production value, sales revenue and the reduced cost (direct cost and general industry cost) difference. The formula used for calculation: Coverage amount $=$ net sales revenues - sales direct $\cos t$ of 
After the basic calculations I have made various indicators:

$\checkmark$ Direct costs: the direct cost of production cost per service or fertility. The formula used for calculation: Direct $\cos t=\frac{\text { total direct } \cos t}{\text { output }}$

$\checkmark$ Direct costing is proportional to profitability: as a percentage of income concept, which shows that the direct cost of production per unit of progress at sectoral level the ratio of how much income. The formula used for calculation:

$$
\text { Direct } \cos \text { ting is proportional to profitability }=\left(\frac{\text { cov erage amout }}{\text { total direct } \cos t}\right) * 100
$$

$\checkmark$ Cost ratio profitability: a specific income concept, which percentage shows that the ratio of how much income achieved per unit cost. The formula used for calculation: Cost ratio profitability $=\left(\frac{\text { revenue above }}{\text { total } \cos t}\right) * 100$

$\checkmark$ Cost level: the production cost production cost is the ratio of. The formula used for calculation: Cost level $=\left(\frac{\cos t \text { of production }}{\text { production value }}\right) * 100$

$\checkmark$ Income level: the ratio of net income to the value of production. The formula used for calculation: Cost level $=\left(\frac{\text { revenue above }}{\text { production value }}\right) * 100$

After defining these indicators of plant production sectors studied were compared. I found that the technology sector, which is more efficient and which one would be worth considering The final calculation of the net present value (NPV) concerns, which expresses that the cash flows (for example plantation at) generated during the entire lifetime of the investment (in my case 12 years) is the sum of the discounted cash flow minus the initial cash flow, how much net income generated.

The formula used for calculation:

$N P V=-C_{0}+\sum\left(\frac{C_{t}}{(1+r)^{t}}\right.$, where "t" is time, "," is the interest rate, $\mathrm{C}_{0}$ is the initial cash flow report.

\section{Results}

\subsection{Costs, costs structure}

Regarding total costs, there are significant differences between the individual plants (Table 3). 12 year costs for maize (Table 3) exceed $11290 €$ per hectare planted, followed by the Arundo at 3.3 million. The Miscanthus and the sunflower show more moderate costs at around $7000-8000 €$ per hectare. The Silphium and the wheat have the least costs over the 12 year period.

Considering the annual average, the order and the differences between the plants is naturally similar to the 12 year averages. The averages, however, hide the time factor related to the pay-back period, since the initial planting costs for the energy plants are 
indeed high, while the annual average for the traditional arable crops is only distorted by the annual rise in prices.

The analysis of the costs by type show significant differences. Maize, which requires intensive plant protection has high material costs (Figure 1), the main proportion of which $(61 \%)$ is represented by chemical costs.

With wheat and sunflowers the material costs are lower, but can still be considered high (28 and $38 \%$ ). Sunflowers and maize have a higher proportion of other direct costs, including drying (Horváth et al., 2009). In the case of energy plants a proportion of machinery and building costs are made up of the rising, and initially high costs of harvesting and harvest-related costs (baling, delivery). Although with all energy plants the cost of reproductive material is quite high, over the 12 years this does not develop into the proportions seen in the traditional arable crops.

Table 3: The cost data on the types of cost of the plants examined over a period of 12 years

\begin{tabular}{|l|c|c|c|c|c|c|}
\hline Appellation & Arundo & Wheat & Maize & Mischantus & Sunflower & Szilfium \\
\hline Material cost & 3051 & 2831 & 6147 & 1680 & 3800 & 1107 \\
\hline Personal costs & 1841 & 523 & 579 & 1557 & 522 & 1366 \\
\hline Machine - building cost & 4906 & 2531 & 2793 & 4248 & 2638 & 3853 \\
\hline Other direct cost & 280 & 120 & 1678 & 240 & 898 & 216 \\
\hline Direct costs total & 10077 & 6005 & 11197 & 7724 & 7858 & 6542 \\
\hline Overall cost & 535 & 303 & 363 & 465 & 329 & 424 \\
\hline All costs & 10612 & 6308 & 11560 & 8188 & 8188 & 6966 \\
\hline
\end{tabular}

Source: Own calculation from the producers received data

material cost $\quad$ Personal costs $\square$ Machine-, building cost $\square$ Other direct cost

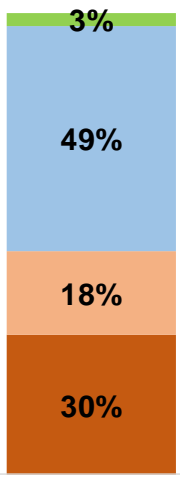

ARUNDO

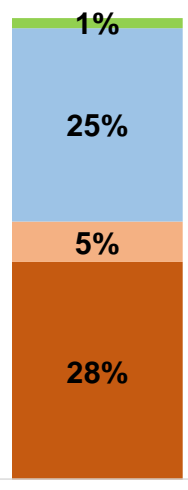

WHEAT

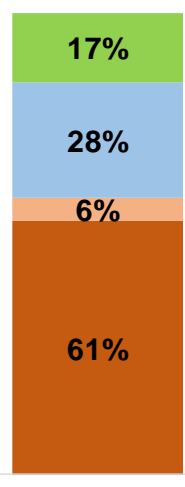

MAIZE

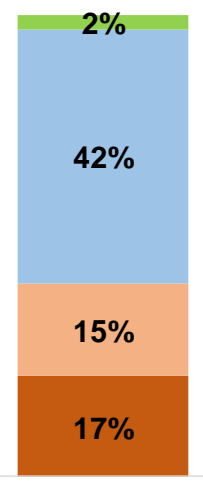

MISCHANTUS

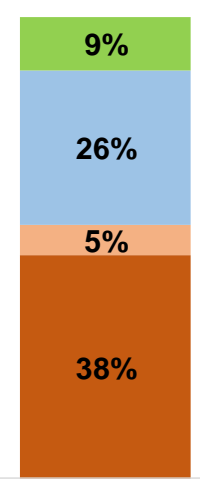

SUNFLOWER

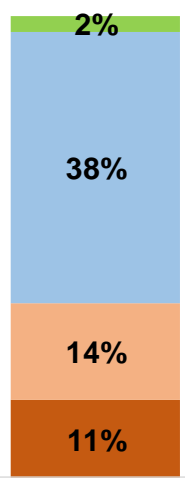

SZILFIUM

Figure 1: The direct distribution of costs per sector and the cost categories Source: Own calculation from the producers received data on the basis

A useful supplement is provided by analysis of the direct operational costs. For maize, wheat and sunflowers, approximately two thirds of the costs are made up of sowing, plant protection and replacing nutrients.

In contrast, the main cost with energy plants is related to harvesting, representing about $50 \%$ (Figure 2). 
From the second and third year, these proportions increase, because the costs related to planting are not repeated. This is strongly connected to the within year financing costs. Financing for traditional arable crops is continuous throughout the year. For example, with maize a significant proportion of the costs appears in the initial period, but the situation is the same with wheat and sunflowers. These plants require short-term 4 to 7 month finance solutions. In contrast, with energy plants a significant proportion of the costs falls in the harvesting period, and so the financing period is reduced to 1 to 2 months, which represents a significant advantage over traditional arable crops. This fact is particularly important in those areas which are in principle economically backward, since in these areas farmers have less capital.

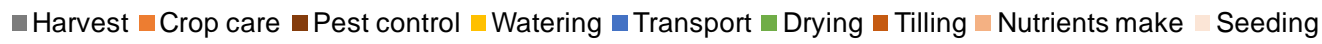

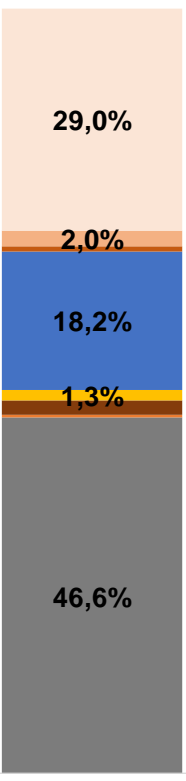

Arundo

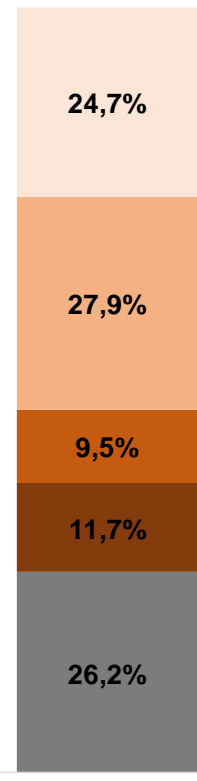

Wheat

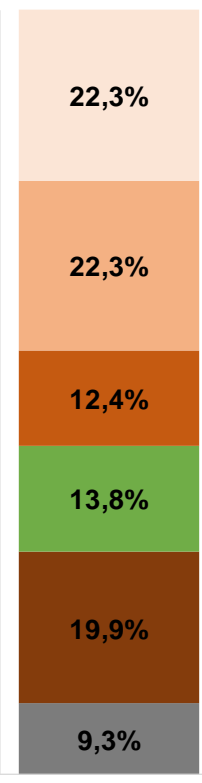

Maize

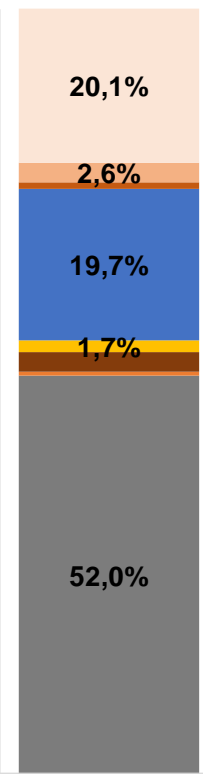

Mischantus

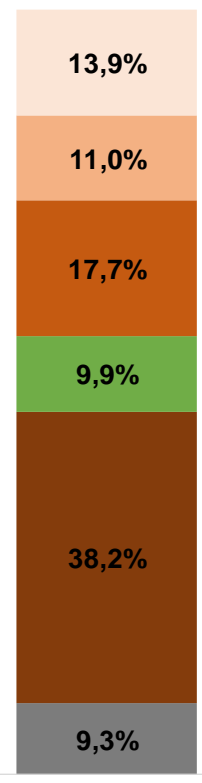

Sunflower

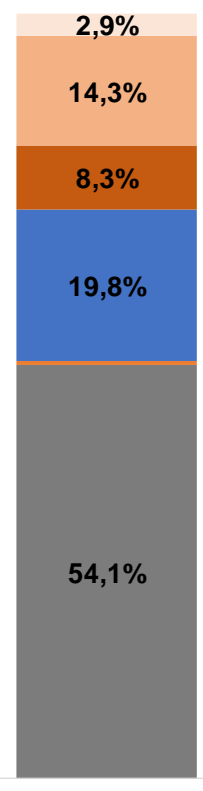

Szilfium

Figure 2: Direct costs per transaction rates in the studied plants

Source: Own calculation from the producers received data on the basis

\subsection{Profitability}

The profitability figures for the different species of energy plants are clearly greater than those for traditional crops. Without exception all of them produce a total $6450 €$ above the break-even point over 12 years, and their per-hectare average indicators are much more favourable (Table 4). Income per hectare, on the basis of our calculations, does not reach that published in the specialist literature, or available on the internet, but the majority of results in the specialist literature are more favourable than ours and most of them contain data from irrigated areas, while the information on the internet has a clearly 'motivational' character in many cases.

Despite all this we can state that energy plants are competitive with traditional arable crops. Considering specific overheads, all three energy crops show similar results, with all three having overhead costs of about $30-32 €$ per tonne sown. Considering that we can calculate a sale price of $55 €$ per tonne, it is clear that we are dealing with high profitability and low costs (Table 5). 
Among the traditional crops, it is only wheat which is capable of competing with these plants, which is understandable, since wheat is also able to produce a crop of suitable size in areas with less favourable characteristics. In contrast, maize and sunflowers are plants more suited to areas with good characteristics.

A traditional cost-income analysis can also produce deceptive results. It is advisable to supplement the analysis with net current values and internal payback rate calculations.

Table 4: The most important cost-income data of the plants examined (12-year totals) measure: EURO

\begin{tabular}{|l|c|c|c|c|c|}
\hline \multicolumn{1}{|c|}{ Plants } & Income & Direct costs & All costs & Net income & Coverage amount \\
\hline Arundo & 19581 & 10077 & 10612 & 8969 & 9504 \\
\hline Wheat & 11292 & 6005 & 6308 & 4984 & 5287 \\
\hline Maize & 14537 & 11197 & 11560 & 2977 & 3340 \\
\hline Mischantus & 16178 & 7724 & 8188 & 7989 & 8454 \\
\hline Sunflower & 10816 & 7858 & 8188 & 2629 & 2958 \\
\hline Szilfium & 13613 & 6542 & 6966 & 6648 & 7072 \\
\hline
\end{tabular}

Source: Own calculation from the producers received data on the basis

Table 5: Cost and profitability indicators per species

\begin{tabular}{|l|c|c|c|c|c|c|}
\hline \multicolumn{1}{|c|}{ Appellation } & Arundo & Wheat & Maize & Mischantus & Sunflower & Szilfium \\
\hline Direct costing $€ / \mathrm{t}$ & 32.0 & 100.1 & 116.6 & 29.7 & 261.9 & 29.7 \\
\hline Overhead €/t & 33.7 & 105.1 & 120.4 & 31.5 & 272.9 & 31.7 \\
\hline $\begin{array}{l}\text { Direct production costs as a } \\
\text { proportion of profitability \% }\end{array}$ & $94 \%$ & $88 \%$ & $30 \%$ & $109 \%$ & $38 \%$ & $108 \%$ \\
\hline $\begin{array}{l}\text { Cost is proportional to } \\
\text { profitability \% }\end{array}$ & $85 \%$ & $79 \%$ & $26 \%$ & $98 \%$ & $32 \%$ & $95 \%$ \\
\hline Cost level \% & $54 \%$ & $56 \%$ & $80 \%$ & $51 \%$ & $76 \%$ & $51 \%$ \\
\hline Income level \% & $46 \%$ & $44 \%$ & $20 \%$ & $49 \%$ & $24 \%$ & $49 \%$ \\
\hline
\end{tabular}

Source: Own calculation from the producers received data on the basis

\subsection{Payback}

In order to provide a firmer basis for comparing the plants' competitiveness, I also analysed the dynamic payback indicators of the individual plants.

In the case of energy plants there is no income in the first year (Horváth et al., 2009), while planting and caring for the seedlings causes significant costs. Table 6 shows these costs. It is clear that the costs of the Italian reed are much higher than those of the Chinese reed and Silphium, although with dibbling the costs of the two plants increase significantly. I carried out a net current value calculation with a discount rate of $5 \%$ and of $8 \%$ (Table 7 ).

Table 6: The first year of the capital required for the production of energy crops $(€)$

\begin{tabular}{|l|l|}
\hline \multicolumn{1}{|c|}{ Tree plantation } & $\boldsymbol{\epsilon}$ \\
\hline Arundo & 3318 \\
\hline Mischantus ${ }^{*}$ & 1947 \\
\hline Szilfium ${ }^{\star *}$ & 408 \\
\hline${ }^{*}$ seedlings with about $645.2 €$ more \\
\hline${ }^{* *}$ seeding technology
\end{tabular}

Source: Own calculation from the producers received data on the basis 
Table 7: The net present value NPV and the internal rate of return evolution

\begin{tabular}{|l|r|r|r|}
\hline \multicolumn{1}{|c|}{ Plants } & \multicolumn{1}{c|}{ IRR } & NPV (5\%) & NPV (8\%) \\
\hline Arundo & $30 \%$ & $6054 €$ & $4550 €$ \\
\hline Mischantus & $41 \%$ & $5622 €$ & $4370 €$ \\
\hline Szilfium & $172 \%$ & $5117 €$ & $4224 €$ \\
\hline Maize & - & $2793 €$ & $2411 €$ \\
\hline Sunflower & - & $2520 €$ & $2156 €$ \\
\hline Wheat & - & $4164 €$ & $3545 €$ \\
\hline
\end{tabular}

Source: Own calculation from the producers received data on the basis

In both cases Arundo finished in the first place, but it is clear that at $8 \%$ its advantage over Miscanthus is already decreasing. Silphium finished behind the other two plants, but its relatively lower initial costs meant that its internal payback rate was higher.

\section{Summary - profitability calculations}

In today's tightening energy situation, energy produced from biomass which can be grown on arable lands has a special importance. Herbaceous energy plants - especially Arundo Donax, Miscanthus and Silphium - have a potential to provide energy biomass for specific purposes. The growth in human population and the rapid paced economic development of the former developing countries is accompanied by higher demands for nutrition, together with an increased thirst for energy. The production of arable biomass energy must be incorporated into this system, such that the process of producing nutrients is affected as little as possible. This means that energy plants must be produced in areas where traditional arable crop production is less competitive. In this study - in the context of the circumstances described above -, we compared the profitability and competitiveness of the herbaceous energy plants mentioned above, with the classic arable crops produced in larger areas in Romania.

On the basis of the results we can state that energy crops are competitive with traditional crops. The initial expenditure can be considered high and the full income only appears in the second-third year, but in the long run the relatively high income and the lower costs after the planting year mean that the expenditures are returned. Payback of the initial costs can be expected in the fifth year for Arundo, in the fourth or fifth year for Miscanthus, and in the second or third year for Silphium. This might appear alarming, but over the 12 year period higher current values are achieved than with traditional crops. I made the calculations without considering any kind of financial supports, but the size of these will not significantly affect the payback periods.

\section{References}

ENER (2012). ENergy Efficiency and Renewables-SUPporting Policies in Local level for EnegY (2012). 'A megújuló energiaforrások kézikönyve'. Jointly for our common future. Környezettudományi Központ. Budapest. ISBN 978-963-08-3749-1

Harmat, Á., Munkácsy, B., Szabó, D. (2011). 'A biomassza energetikai hasznosításának jövőképe'. In: Munkácsy Béla (2011): Erre van elöre! Egy fenntartható energiarendszer keretei Magyarországon - Vision 2040 Hungary 1.0. ISBN 978-963-08-2024-0. pp. 87-103. Horváth, Zs., Vágvölgyi, A., Pintér, Cs., Marosvölgyi, B. (2009). 'Új szaporítóanyag-előállítási lehetőségek vizsgálata Miscanthus sinensis energianövénnyel. 
Nyíradony-Gúthpuszta Konferenciakiadvány. Alföldi Erdőkért Egyesület. Kutatói nap. Tudományos eredmények a gyakorlatban. pp. 89-93.

INS, (2012). National Institute of Statistics. 'Agricultural holdings, number of persons, by gender, and number of worked days, by size classes of number of worked days, by legal status of agricultural holding', available from http://www.insse.ro/cms/ro/content/ancheta-structural\%C4\%83-\%C3\%AEn-agricultur\%C4 $\% 83-2013$-date-pe-macroregiuni-regiuni-de-dezvoltare-\%C5\%9Fi-jude\%C5\%A3e [05.02.2017].

INS (2016). National Institute of Statistics. 'Ancheta Structurală în Agricultură 2016 Date pe Macroregiuni, regiuni de dezvoltare şi judeţe - Volumul II', available from http://www.insse.ro/cms/ro/content/ancheta-structural\%C4\%83-\%C3\%AEn-agricultur\%C4 $\% 83-2016$-date-pe-macroregiuni-regiuni-de-dezvoltare-\%C5\%9Fi-jude\%C5\%A3e [17.01.2017].

OECD-FAO (2010). OECD-FAO (Food and Agriculture Organization of the United Nations) Agricultural Outlook 2015-2024. 'Overview of the OECD-FAO Agricultural Outlook 2015-2024.' Paris. ISBN 978-92-64-23190-0

Robertson, A.W., Khail, M.A.K. (1984). 'Conifers for Biomass production'. Vol. I. Forest Energy Program, Canadian Forestry Service and I.E.A. In. W. Palz - J. Coombs - D.O. Hall: Energy from biomass 3rd E.C. Conference Elsevier applied science publishers. Brussels and Luxemburg. ISBN 0-85334-3969. pp. 303-315.

\section{Bio-note}

Margit Csipkés, Ph.D. is a senior lecturer at University of Debrecen Faculty of Economics and Business, Institute of Sectoral Economics and Methodology. Her research topic is the traditional arable crops, energy crops and land use role. She earned PhD in economic analysis of individual power plants as well as their impact on land use. She is currently researching the energy management policies of Hungary and surrounding countries. In this respect, she typically uses statistical methods, $R$ program, linear programming and economic analysis. 